GHANI, MA; ABBAS, MM; ZIAF, K; AZAM, M; ALI, B; AMJAD, M; ANJUM, R; NOOR, A; ZAHID, M. 2020. Production and characterization of inter and intraspecific hybridization eggplant. Horticultura Brasileira 38: 407-414. Doi: http://dx.doi.org/10.1590/s0102-0536202004011

\title{
Production and characterization of inter and intraspecific hybridization eggplant
}

\author{
Muhammad A Ghani ${ }^{1} \mathbb{D}$; Muhammad M Abbas ${ }^{1} \mathbb{D}$; Khurram Ziaf ${ }^{1} \mathbb{D}$; Muhammad Azam ${ }^{1} \mathbb{D}$; Basharat \\ Ali ${ }^{2} \mathbb{D}$; Muhammad Amjad ${ }^{1} \mathbb{D}$; Romana Anjum ${ }^{3} \mathbb{D}$; Anam Noor ${ }^{1} \mathbb{D}$; Mubashir Zahid ${ }^{1 \mathbb{D}}$
}

${ }^{1}$ Institute of Horticultural Sciences, University of Agriculture, Faisalabad, Pakistan; awais.ghani@uaf.edu.pk (author for correspondence); mehranabbas2074@gmail.com; khurramziaf@uaf.edu.pk; muhammad.azam@uaf.edu.pk; amjaduaf@gmail.com; anamnoor83@gmail. com; mubashirzahid@live.com; ²Department of Agronomy, University of Agriculture, Faisalabad, Pakistan; basharat2018@yahoo.com; ${ }^{3}$ Department of Plant Pathology, University of Agriculture, Faisalabad, Pakistan; romana.anjum@uaf.edu.pk

\begin{abstract}
The eggplant is a highly valuable horticultural crop grown all over the world and it is of substantial economic importance in Asia. However, its production is severely threatened by several soil-borne and foliar diseases, insect-pests, drought, heat, and frost damage. Therefore, efforts to transfer useful resistance genes into eggplant from their wild relatives is important. In the present study, interspecific and intraspecific hybridization was carried out, that included three cultivated genotypes of eggplant (Solanum melongena MEE, Solanum melongena MEP, Solanum melongena MEB) and one wild Solanum species (Solanum incanum $\mathrm{INC}$ ). The $\mathrm{F}_{1}$ hybrids were made by inter and intraspecific hybridization. A total of 632 possible inter and intraspecific reciprocal crosses was performed where only three were successful. The minimum days to flowering were observed in parent MEP, and maximum plant height was measured in MEE $\times$ MEB. Maximum fruit length was observed in parent MEB. Furthermore, fruit diameter, leaf width, leaf length, and fruit yield per plant were found maximum in hybrid MEExINC. Our results suggest that these materials will be of great interest for the genetic improvement of eggplant; they may have a tremendous potential to increase tolerance to abiotic stresses, such as to drought and heat, as well as increased nutrient and herbal values. Findings of this study will be helpful for the human health, ultimately contributing to the development of a new generation of plants adapted to climate.
\end{abstract}

Keywords: Solanum melongena, Solanum incanum, Solanaceae, hybrid, heterosis, yield, wild species.

\begin{abstract}
RESUMO
Produção e caracterização de berinjela de hibridização inter e intraespecífica
\end{abstract}

A berinjela é uma cultura hortícola muito valorizada, cultivada em todo o globo e de grande importância econômica na Ásia. No entanto, sua produção está ameaçada por várias doenças foliares ou transmitidas pelo solo, pragas, seca, calor e danos causados por geada. Portanto, esforços são importantes para transferir genes de resistência para a berinjela, provenientes de seus parentes selvagens. No presente estudo, foi realizada hibridização interespecífica e intraespecífica, que incluiu três genótipos cultivados de berinjela (Solanum melongena MEE, Solanum melongena MEP, Solanum melongena MEB) e uma espécie selvagem de Solanum (Solanum incanum INC). Os híbridos F1 foram produzidos por hibridização inter e intraespecífica. Um total de 632 cruzamentos recíprocos inter e intraespecíficos possíveis foram realizados, onde apenas três tiveram sucesso. Os dias mínimos para o florescimento foram observados na MEP parental, e a altura máxima da planta foi medida em MEE $\times$ MEB. O comprimento máximo do fruto foi observado na MEB parental. Além disso, o diâmetro do fruto, a largura da folha, o comprimento da folha e a produção de frutos por planta foram encontrados máximos no híbrido MEExINC. Nossos resultados sugerem que esses materiais serão de grande interesse para o melhoramento genético da berinjela; eles podem ter enorme potencial para aumentar a tolerância aos estresses abióticos, como seca e calor, bem como aumentar os valores nutricionais. Os resultados encontrados neste estudo serão úteis para a saúde humana, em última análise, contribuindo para o desenvolvimento de uma nova geração de plantas adaptadas ao clima.

Palavras-chave: Solanum melongena, Solanum incanum, Solanaceae, híbrido, heterose, produção, espécie selvagem.

\section{Received on June 16, 2020; accepted on September 6, 2020}

$\mathrm{R}$ elative wild species can contribute to spread the genetic background of crops and adapt them to new challenges, such as climate change, tolerance to abiotic and biotic stresses (Dempewolf et al., 2014). The utilization of wild relatives in crop breeding has economic impact at the global level in $164.5 \cdot 10^{9}$ US\$ annually. Current improvement of the crops by using wild relatives in breeding has gained more importance in the climate change scenario besides conferring resistance to different diseases (Tyack \& Dempewolf, 2015).
This clearly shows how research in crop wild relatives and its utilization in breeding may have an important economic impact by developing new cultivars with improved characteristics.

One of the vegetables, in which significant efforts are being done in 
the last years for interspecific breeding from related species for adaptation to climate change, is the common eggplant (Solanum melongena) (Liu et al., 2015; Plazas et al., 2016). The eggplant belongs to the Solanaceae family, which is a highly valuable horticultural crop grown all over the world and it is of substantial economic importance in Asia, Africa, and the subtropics (Collonnier et al., 2001). It is a good source of proteins, minerals, and antioxidant and also has medicinal value (Magioli \& Mansur, 2005). However, its production is severely threatened by several soilborne and foliar diseases, insect-pests, drought, heat and frost damage, which reduce yield (Collonnier et al., 2001). Therefore, efforts to transfer useful resistance genes into eggplant from the wild relatives are important because of the lack of resistance in common eggplant gene pool.

Eggplant wild species (Solanum incanum, also known as Sodom or thorn apple) is found growing naturally in both tropics and subtropics (Waweru et al., 2017) and has been regarded as wild progenitor of Solanum melongena (Prohens et al., 2013). It is herbaceous or a soft wooded shrub having spiny stem and leaves covered with velvety hairs. Its extract is used to control ticks in cattle (Mwaura et al., 2011). Moreover, its fruit has been used to cure mycotic infections in Africa. Compost is also prepared by this wild plant (Mwaura et al., 2011). Furthermore, extract of its fruit has been used to control nematode (Meloidogyne spp.) in Capsicum annuum (Waweru et al., 2017) and so it can be used as an environmentally safe nematicide. It is believed to contain high quantity of phenolic compounds and therefore can be used in improvement of eggplant quality through breeding (Prohens et al., 2013). However, Kaushik et al. (2016) reported small fruit size of the hybrids developed by crossing cultivated eggplant with Solanum incanum. Mangino et al. (2020) evaluated the performance of 16 introgression lines (ILs) containing chromosomal segments of $S$. incanum and reported improved vigour in the ILs but exhibited low value of various fruit related parameters. Availability of large number of accessions (167) of $S$. incanum (Taher et al., 2017) offers to select the best performing one for distant hybridization.

Inter and intraspecific hybridization transfers desired genes from one specie to the other or same species which play an important role to improve the crop yield and disease resistance (Ghani et al., 2020). Interspecific hybridization is an important approach in plant breeding to incorporate useful genes to crop improvement (Sekara et al., 2007). The wild species of eggplant are a rich source of genes for resistance to diseases or insects. For example, bacterial wilt resistance in $S$. aethiopicum. (Collonnier et al., 2001); resistance to little leaf, shoot and fruit borer in $S$. indicum (Bahgat et al., 2008); Verticillium and Fusarium wilt resistance in $S$. incanum (Prohens et al., 2013). However, in interspecific hybridization, the production of hybrid seed is greatly hampered due to certain fertilization barriers. The crossability and hybridization studies of different $S$. melongena accessions with its related species have been carried out with inconsistent results (Behera \& Singh, 2002). Crossability of $S$. melongena with $S$. incanum has also been reported (Kumar et al., 2020). The breeding materials developed through this program will help in further improvement of eggplant particularly in resistance breeding, but the fruit weight is reduced, particularly in $S$. incanum (Kumar et al., 2020).

The identification of hybrids relies on both morphological traits and molecular markers. Different molecular markers, including RAPD, AFLPs, and SSR have been used in plant genetic analysis. In the present study, a marker system called sequence related amplified polymorphism (SRAP) was chosen because it is simple, reproducible and comparatively less expensive than other types of markers (Li \& Quiros, 2001). Moreover, SRAP is also more informative than RAPD, ISSR, SSR, AFLP (Budak et al., 2004). With respect to true hybrid, SRAPs have provided a reliable tool for the estimation of the degree of genetic relatedness among number of species in the plant kingdom
(Li \& Quiros, 2001). Thus, SRAP markers are commonly used as they are rapid, simple, and cost effective to access the genetic purity of interspecific and intraspecific hybrids.

In the present study, we reported the successful interspecific hybridization of eggplant and its wild relative $S$. incanum. We tried to describe the characteristics of intraspecific and interspecific hybrids between S. melongena x S. melongena and $S$. melongena $\mathrm{x}$ S. incanum and found positive gain in fruit size and fruit yield per plant compared to the parents. Given the high quality (phenolic contents) of $S$. incanum, and tolerance to drought and resistance to a few diseases (Prohens et al., 2013: Mangino et al., 2020) as well as suitability as rootstock (Gisbert et al., 2011), these materials may be of great interest for developing a new generation of eggplant varieties adapted to climate change and tolerance to drought and heat stress.

\section{MATERIAL AND METHODS}

\section{Plant materials}

A two-year experiment was conducted at Vegetable Research Farm, Institute of Horticultural Sciences, University of Agriculture, Faisalabad, Pakistan $\left[30-31.5^{\circ} \mathrm{N}, 73-74^{\circ} \mathrm{E}, 184 \mathrm{~m}\right.$ altitude $(604 \mathrm{ft}$.)]. The three accessions of $S$. melongena and one $S$. incanum were collected from Asian Vegetable Research and Development Center (AVRDC). These germplasms were collected due to their different characters: S. melongena (MEE, VI042556) has spiny leaves and oblong purple fruit, $S$. melongena (MEP, VI041674) has white slightly curved long and purple fruit, S. melongena (MEB, VI042569) has snake shaped long purple fruit and $S$. incanum (INC, VI048616) a wild specie has round shape and small green fruit.

\section{Morphological parameters}

Different morphological parameters were observed i.e. leaf length, leaf width, plant height, fruit length and fruit diameter. Leaf dimensions were recorded by taking measurements of three mature leaves from each plant at the vegetative phase. Plant height was 
measured after flowering while fruit length and fruit diameter were obtained from mature fruit. These parameters were taken by using meter scale. Fruits were harvested at maturity and yield per plant was determined.

\section{Pollen viability}

The mature flower buds were bagged with butter paper bag one day before anthesis for the pollen viability assessment. Three to four flowers were collected of each wild and cultivated species at 8 a.m. on the day of anthesis. Fresh pollen from anthers of each flower of parents and $F_{1}$ were shattered on microscope glass slide and stained with $1 \%(\mathrm{w} / \mathrm{v})$ acetocarmine. After drying of acetocarmine, slides were examined under microscope $(400 \mathrm{X})$ using the method described by Alexander (1969).
SRAP (Sequence related amplified polymorphism) analysis

Eggplant six SRAP primers were selected from sequence previously reported (Li \& Quiros, 2001). For this purpose, these six pair of primers were used Forward primer (Table 1). A modified version of the CTAB method was used to extract genomic DNA. PCR amplification was performed under the following conditions: $5 \mathrm{~min}$ of denaturing at $94^{\circ} \mathrm{C}$, and 5 cycles of three steps, including $1 \mathrm{~min}$ of denaturing at $94^{\circ} \mathrm{C}, 1 \mathrm{~min}$ of annealing at $35^{\circ} \mathrm{C}$ and $1 \mathrm{~min}$ of elongation at $72^{\circ} \mathrm{C}$. This was followed by 35 cycles of $94^{\circ} \mathrm{C} / 45 \mathrm{~s}, 50^{\circ} \mathrm{C} / 45 \mathrm{~s}, 72^{\circ} \mathrm{C} / 1 \mathrm{~min}, 1$ cycle of $72^{\circ} \mathrm{C}$ for $10 \mathrm{~min}$ at $4^{\circ} \mathrm{C}$. Each PCR product $(6 \mu \mathrm{L})$ was resolved in $6 \%$ denaturing poly acryl-amide gel electrophoresis (PAGE) at $1500 \mathrm{~W}$ for $2.5 \mathrm{~h}$. The amplified products were visualised by simplified silver staining. In order to obtain reproducible and clear banding patterns, each amplification was repeated three times, and only bands showing consistent amplifications were scored.

\section{Statistical analysis}

The statistical analyses were carried out by using Statistix 8.1 software. Standard deviation (SD) was also calculated. Complete randomize block design (RCBD) was used and also for the pair-wise comparisons least significant difference (LSD) test was used with $95 \%(\mathrm{p}<0.05)$ confidence.

\section{RESULTS AND DISCUSSION}

Table 1. List of eggplant SRAP markers. Faisalabad, University of Agriculture, 2019.

\begin{tabular}{|c|c|c|}
\hline Pair no. & Forward primers & Reverse primers \\
\hline 1 & me1, 5'-TGAGTCCAAACCGGATA-3' & em2, 5'-GACTGCGTACGAATTTGC-3' \\
\hline 2 & me3, 5'-TGAGTCCAAACCGGAAT-3' & em4, 5'-GACTGCGTACGAATTTGA-3' \\
\hline 3 & me1, 5'-TGAGTCCAAACCGGATA-3' & em1, 5'-GACTGCGTACGAATTAAT-3' \\
\hline 4 & me2, 5'-TGAGTCCAAACCGGAGC-3' & em2, 5'-GACTGCGTACGAATTTGC-3' \\
\hline 5 & me1, 5'-TGAGTCCAAACCGGATA-3' & em4, 5'-GACTGCGTACGAATTTGA-3' \\
\hline 6 & me2, 5'-TGAGTCCAAACCGGAGC-3' & em4, 5'-GACTGCGTACGAATTTGA-3' \\
\hline
\end{tabular}

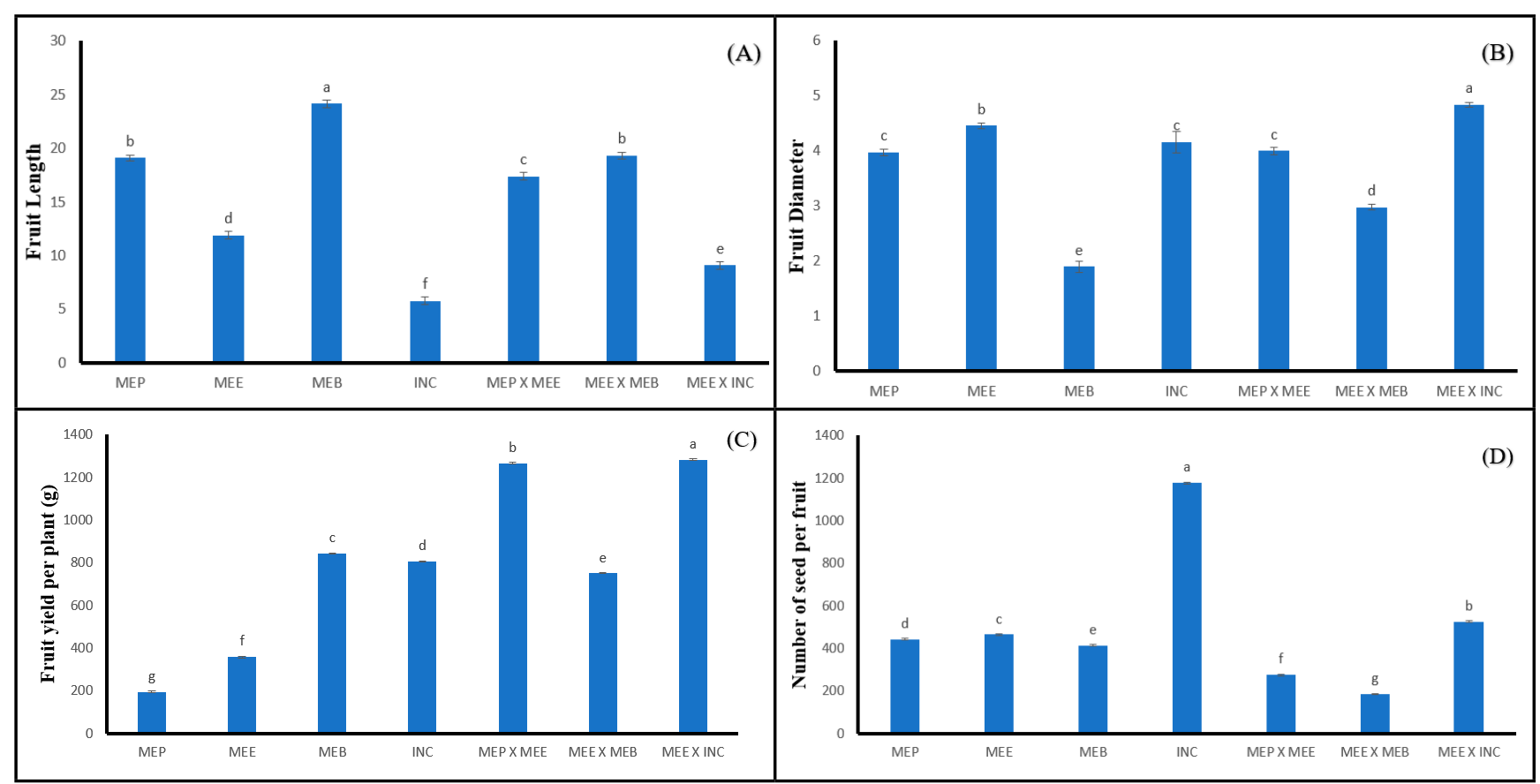

Figure 1. A) Variations in fruit length $(\mathrm{cm}) ; \mathrm{B})$ fruit diameter $(\mathrm{cm})$; C) fruit yield per plant $(\mathrm{g})$ and D) number of seeds per fruit among parents and their hybrids. Parents: MEP, MEE, MEB, INC and hybrids: MEPxMEE, MEExMEB, MEExINC. Faisalabad, University of Agriculture, 2019. 


\section{Inter and intraspecific crossing}

Intraspecific hybrids were produced by using different cross combinations (Table 2). Highest hybridization resemblance was observed in MEE $\times$ MEB with a $14.81 \%$ successful cross ratio than other combinations. On the other hand, different cross combinations with $S$. incanum were also performed to produce $F_{1}$ interspecific hybrids. In this cross-success ratio $6.12 \%$ was observed in MEE $\times$ INC combination, but its reciprocal was unsuccessful. The MEE $\times$ INC hybrid had the maximum number of seeds per fruit (Table 2).

\section{Morphological observation}

The crossability among the $S$.

Table 2. Total number of cross combinations of inter and intraspecific hybridization of eggplant. Faisalabad, University of Agriculture, 2019.

\begin{tabular}{lcccc}
\hline Combination & $\begin{array}{c}\text { No. of } \\
\text { crosses }\end{array}$ & $\begin{array}{c}\text { No. of fruit } \\
\text { setting }\end{array}$ & $\begin{array}{c}\text { Successful } \\
\text { cross (\%) }\end{array}$ & $\begin{array}{c}\text { No. of seeds/ } \\
\text { fruit }\end{array}$ \\
\hline MEE $\times$ MEB & 54 & 8 & 14.81 & 190 \\
MEE $\times$ INC & 49 & 3 & 6.12 & 550 \\
MEP $\times$ MEE & 50 & 7 & 14.00 & 250 \\
MEP $\times$ MEB & 34 & 0 & 0.00 & 0.00 \\
MEP $\times$ INC & 58 & 0 & 0.00 & 0.00 \\
MEB $\times$ MEP & 41 & 0 & 0.00 & 0.00 \\
MEB $\times$ MEE & 29 & 0 & 0.00 & 0.00 \\
MEB $\times$ INC & 58 & 0 & 0.00 & 0.00 \\
INC $\times$ MEP & 70 & 0 & 0.00 & 0.00 \\
INC $\times$ MEB & 61 & 0 & 0.00 & 0.00 \\
INC $\times$ MEE & 62 & 0 & 0.00 & 0.00 \\
MEE $\times$ MEP & 66 & 0 & 0.00 & 0.00 \\
\hline
\end{tabular}

melongena genotypes with their wild relatives showed wide range of variations in morphological characters. The interspecific hybrids were intermediate in most of the parental characteristics. This is a common phenomenon in interspecific hybrids in eggplant with wild relatives (Prohens et al., 2013: Kaushik et al., 2016). The hybrid $\mathrm{F}_{1}$ plants were evaluated by visual morphological observation of parents and their hybrid plants. The observations pertaining to the following characters were recorded on three randomly obtained competitive plants from each treatment (Table 3). At seedling stage $\mathrm{F}_{1}$ hybrids were no significant different from parents. To produce hybrids, different cross combinations were performed between MEP, MEB, MEE and INC (Table 3). Cotyledons length results indicated that the parent MEP has maximum length $(3.22 \mathrm{~cm})$ while minimum length was recorded in MEB $(1.46 \mathrm{~cm})$ compared to hybrids. However, the MEP $\times$ MEB hybrid had the highest cotyledon width $(0.51 \mathrm{~cm})$ while MEE had lowest cotyledon width compared to other parents and hybrids (Table 3 ). The hybrid MEP $\times$ MEB

Table 3. Morphological observations along with pollen viability test of parents and their hybrids. Parents; MEP, MEE, MEB, INC and hybrids; MEPxMEE, MEExMEB, MEExINC. Faisalabad, University of Agriculture, 2019.

\begin{tabular}{lccccccc}
\hline Characteristics & MEP & MEE & MEB & INC & $\begin{array}{c}\text { MEP x } \\
\text { MEE }\end{array}$ & $\begin{array}{c}\text { MEE x } \\
\text { MEB }\end{array}$ & $\begin{array}{c}\text { MEE x } \\
\text { INC }\end{array}$ \\
\hline Cotyledon length $(\mathrm{cm})$ & $3.22 \mathrm{a}$ & $2.56 \mathrm{bc}$ & $1.46 \mathrm{~d}$ & $3 \mathrm{ab}$ & $2.62 \mathrm{e}$ & $2.7 \mathrm{f}$ & $2.38 \mathrm{c}$ \\
Cotyledon width $(\mathrm{cm})$ & $0.5 \mathrm{a}$ & $0.2 \mathrm{~d}$ & $0.33 \mathrm{bc}$ & $0.394 \mathrm{bc}$ & $0.434 \mathrm{ab}$ & $0.51 \mathrm{a}$ & $0.436 \mathrm{ab}$ \\
Plant height $(\mathrm{cm})$ & $51.48 \mathrm{c}$ & $51.4 \mathrm{c}$ & $43.64 \mathrm{~d}$ & $43.88 \mathrm{~d}$ & $61.88 \mathrm{~b}$ & $66.26 \mathrm{a}$ & $62.42 \mathrm{~b}$ \\
Plant Growth habit & intermediate & intermediate & upright & upright & upright & prostrate & upright \\
Stem diameter (cm) & $1.72 \mathrm{c}$ & $2.89 \mathrm{a}$ & $2.1 \mathrm{bc}$ & $1.61 \mathrm{~d}$ & $3.12 \mathrm{ab}$ & $1.64 \mathrm{~b}$ & $2.26 \mathrm{bc}$ \\
Leaf length $(\mathrm{cm})$ & $20.2 \mathrm{c}$ & $23.1 \mathrm{~b}$ & $21.1 \mathrm{c}$ & $22.6 \mathrm{~b}$ & $27.6 \mathrm{a}$ & $23.54 \mathrm{~b}$ & $28.1 \mathrm{a}$ \\
Leaf width $(\mathrm{cm})$ & $11.86 \mathrm{c}$ & $10.5 \mathrm{~b}$ & $14.5 \mathrm{a}$ & $11.258 \mathrm{ab}$ & $11.726 \mathrm{~d}$ & $14.6 \mathrm{abc}$ & $15.1 \mathrm{ab}$ \\
Leaf petiole length $(\mathrm{cm})$ & $4.748 \mathrm{e}$ & $6.694 \mathrm{~cd}$ & $6.324 \mathrm{~d}$ & $7.164 \mathrm{bc}$ & $8.756 \mathrm{a}$ & $7.176 \mathrm{bc}$ & $7.66 \mathrm{~b}$ \\
Leaf blade color & green & light green & dark green & light green & dark green & green & green \\
Days to flowering & $61.6 \mathrm{e}$ & $94.4 \mathrm{~b}$ & $106 \mathrm{a}$ & $63.4 \mathrm{e}$ & $80.2 \mathrm{c}$ & $78 \mathrm{~cd}$ & $76.4 \mathrm{~d}$ \\
Corolla color & pale violet & white & bluish violet & light violet & light violet & pale violet & light violet \\
Sepal length $(\mathrm{cm})$ & $2.15 \mathrm{a}$ & $1.754 \mathrm{c}$ & $2.164 \mathrm{a}$ & $1.862 \mathrm{~b}$ & $1.756 \mathrm{c}$ & $1.664 \mathrm{~d}$ & $1.656 \mathrm{~d}$ \\
Petal length $(\mathrm{cm})$ & $2.752 \mathrm{~b}$ & $2.862 \mathrm{a}$ & $2.452 \mathrm{~d}$ & $2.866 \mathrm{a}$ & $2.806 \mathrm{~b}$ & $2.578 \mathrm{c}$ & $2.726 \mathrm{c}$ \\
*Fertile & $70.1\left(18.8^{\mathrm{cd}}\right)$ & $40.9\left(16.2^{\mathrm{d}}\right)$ & $42.4\left(19.2^{\mathrm{ab}}\right)$ & $42.6\left(21.6^{\mathrm{bc}}\right)$ & $63.4\left(26.4^{\mathrm{b}}\right)$ & $38.9\left(17.2^{\mathrm{e}}\right)$ & $61.1\left(32.4^{\mathrm{a}}\right)$ \\
$*$ Semi fertile & $35.07\left(9.4^{\mathrm{e}}\right)$ & $59.09\left(23.4 \mathrm{~b}^{\mathrm{c}}\right)$ & $65.04\left(29.4^{\mathrm{a}}\right)$ & $60.8\left(30.8^{\mathrm{a}}\right)$ & $36.5\left(15.2^{\mathrm{d}}\right)$ & $61.08\left(27^{\mathrm{c}}\right)$ & $\left(20.6^{\mathrm{c}}\right)$ \\
\hline
\end{tabular}

*The category was based on the assessment of Devi et al. (2015). Means with the same letter are not significantly different. 


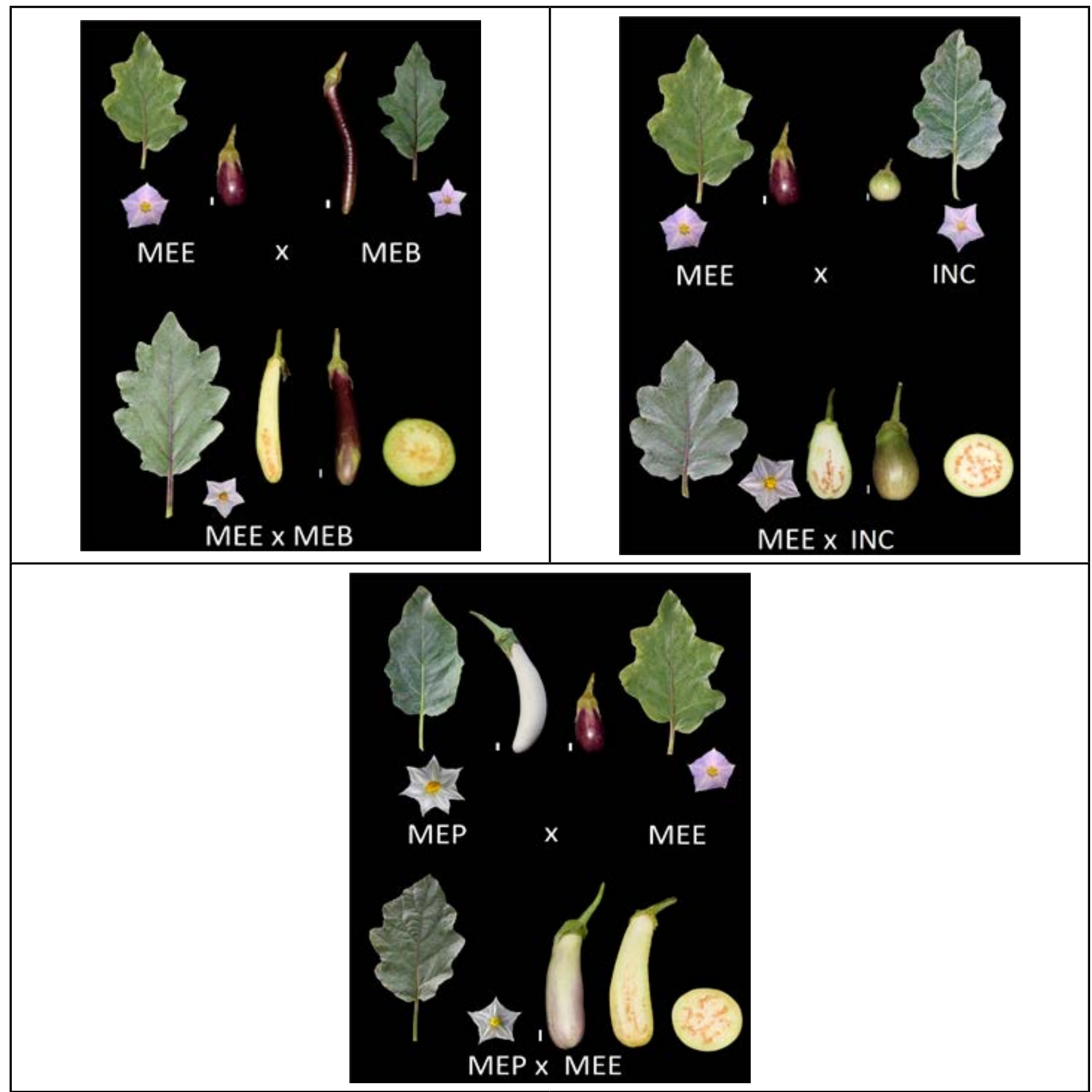

Figure: 2a. The inter and intraspecific hybridization have shown the comparison between the hybrid leaves, flowers and fruits with their parents. Parents: MEP, MEE, MEB, INC and hybrids; MEPxME. Faisalabad, University of Agriculture, 2019.

gained maximum plant height $(66.26$ $\mathrm{cm}$ ), while the parent MEB exhibited minimum height about $43.64 \mathrm{~cm}$ than the other parents and hybrids (Table 3). The maximum stem diameter was observed in hybrid MEPxMEE other than hybrids and parents (Table 3 ). Leaves are main sites for photosynthetic reaction and play a key role in fruit size and yield (Shakoor et al., 2010). In interspecific crosses, wild parent INC showed intermediate length, width and leaf petiole length. MEE $\times$ INC hybrid had the highest leaf length $(28.1 \mathrm{~cm})$ and leaf width $(15.1 \mathrm{~cm})$ compared to parents and hybrids. The hybrid MEP $\times$ MEE showed maximum petiole length $(8.75 \mathrm{~cm})$, while the parent MEP minimum petiole length $(4.748 \mathrm{~cm})$ than the other parents and hybrids. However, the flower is a most critical reproductive part of the plant which plays key role in yield of plants. Moreover, Haydar et al. (2007) also found that the days taken for flower setting is directly related to the fruit yield in tomato. Parent MEP has minimum days to flowering about 61.6 days than the other parents and hybrids. The maximum sepal length was measured in parent MEB $(2.16$ $\mathrm{cm})$ and minimum length was 1.66 $\mathrm{cm}$ in hybrid MEE $\times$ INC (Table 3). Highest petal length was measured in 


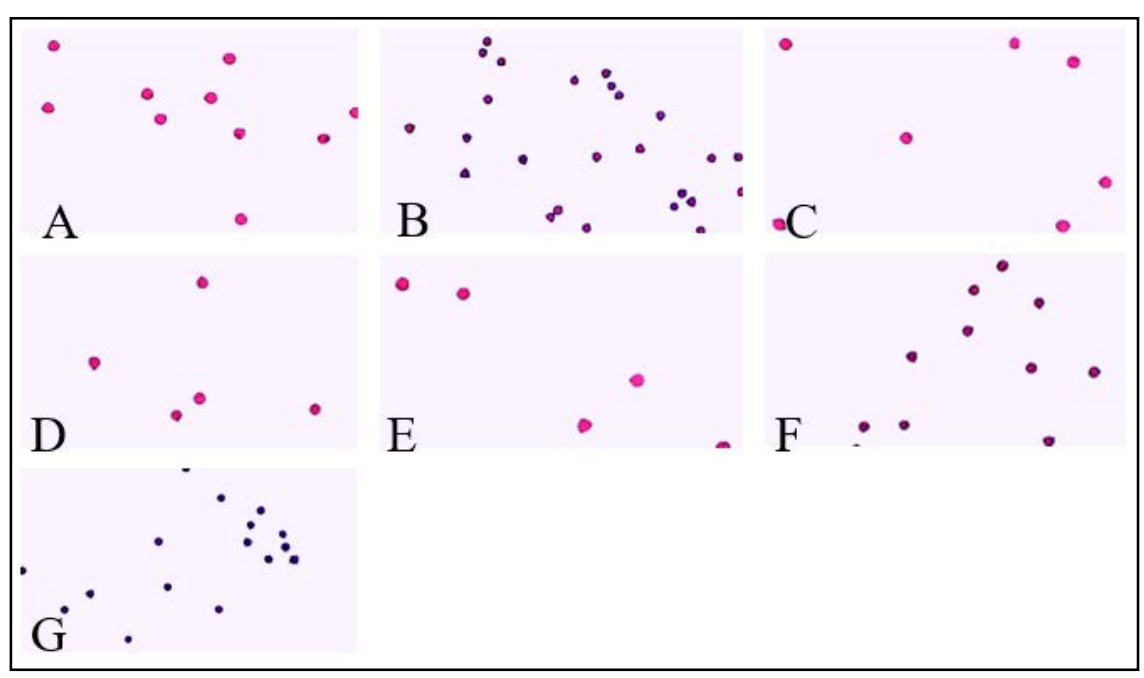

Figure 2b. Pollen fertility of parents, (A) INC (semi-fertile), (B) MEP (fertile), (C) MEE (semi-fertile), (D) MEB (semi-fertile), and pollen fertility of hybrids (E) MEExMEB, (semi-fertile) (F) MEExINC (fertile), (G) MEPxMEE (fertile). Faisalabad, University of Agriculture, 2019.

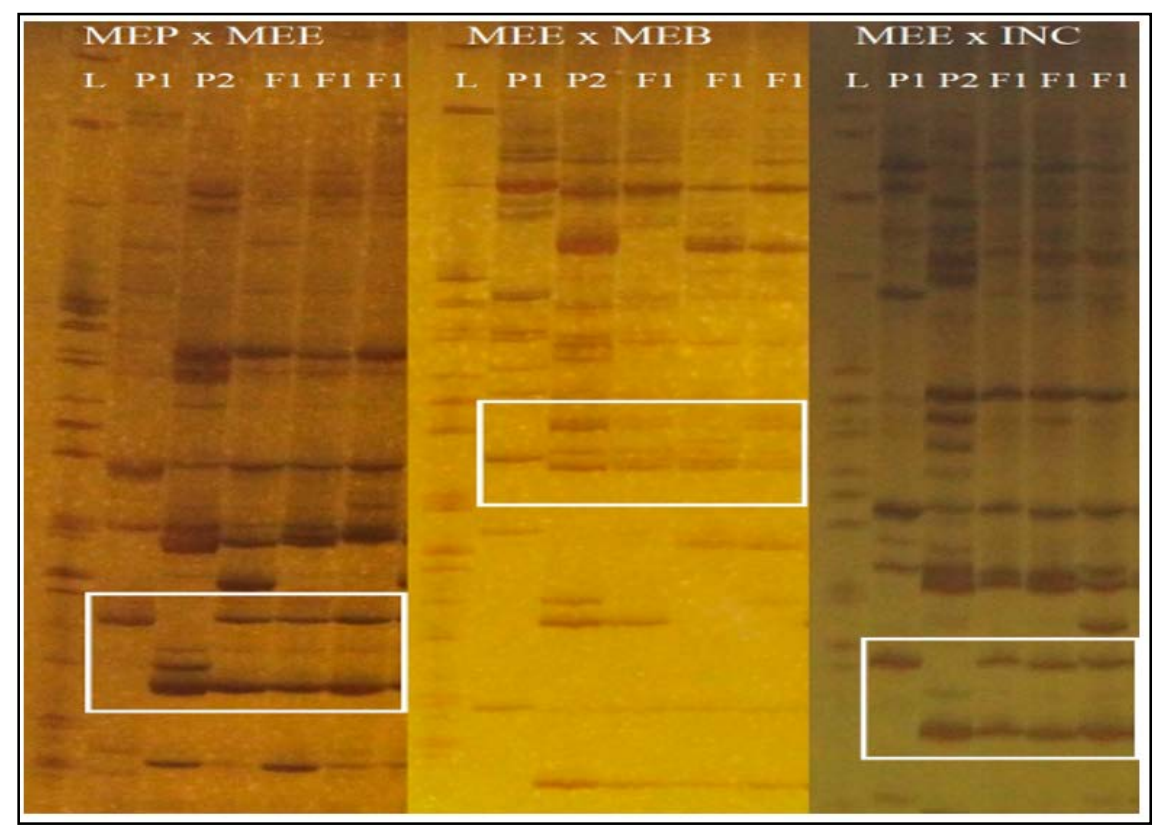

Figure 2c. Analysis on SRAP result of inter and intraspecific (F1) hybrid and their parent lines using markers. L: leader; P: parents. $F_{1}$ hybrids. Parents: MEP, MEE, MEB, INC and hybrids: MEPxMEE, MEExMEB, MEExINC. Faisalabad, University of Agriculture, 2019.

INC $(2.87 \mathrm{~cm})$; on the other hand, the lowest petal length was observed in hybrid MEE $\times$ MEB $(2.57 \mathrm{~cm})$ (Table 3). Stamen length results indicated that maximum length was $1.54 \mathrm{~cm}$ in hybrid MEE $\times$ INC and minimum length was $1.36 \mathrm{~cm}$ in INC (Table 3). The fruit length was observed maximum (24.16 $\mathrm{cm})$ in MEB parents compared to other parents and hybrids (Figure 1a). But the fruit diameter was maximum $(4.84 \mathrm{~cm})$ in MEE $\times$ INC hybrid other than parents and hybrids (Figure 1b). The parent INC showed maximum pedicle length (7 $\mathrm{cm})$, while the parent MEB possessed minimum pedicle length $(3.18 \mathrm{~cm})$ than the other parents and hybrids (Table $2)$. The highest fruit pedicle thickness was recorded in parent INC $(1.16 \mathrm{~cm})$ while minimum fruit pedicle thickness $(0.6 \mathrm{~cm})$ was recorded in MEE. Fruit yield was measured on per plant basis and the results indicated that the hybrid MEE $\times$ INC had highest fruit yield $1283.8 \mathrm{~g}$ while, on the other hand, parent MEP had lowest fruit yield per plant (194.4 g) among all parents and hybrids (Figure 1c). Interspecific hybridization between cultivated eggplant and its wild relatives is an important way of deploying desirable genes for eggplant improvement (Liu et al., 2015). In this study, the MEE x INC hybrid was successfully obtained by crossing cultivated eggplant and $S$. incanum. However, when $S$. incanum was used as female, no fruit setting was observed, whereas only cross combinations of cultivated eggplant and $S$. incanum showed fruit setting when $S$. incanum was used as male. Most of the attempts to produce interspecific hybrids have resulted in sterility between the eggplant $S$. melongena and its wild relatives (Nasrallah \& Hopp, 1963). Latest literature described that the hybrids of $S$. melongena x $S$. incanum and $S$. incanum $\times S$. melongena were fertile and produced seeds (Kaushik et al., 2016). The INC parent had highest number of seeds per fruit (1177.2) and the lowest numbers of seeds (185) was recorded in MEE $\times$ MEB as compared to parents and hybrids (Figure 1d). The maximum number of seeds per fruit was also found in S. melongena $\mathrm{x} S$. incanum as compared to parents and other hybrids (Figure 2a). Higher number of seeds per fruit was also reported in a cross between $S$. melongena x $S$. incanum (Plazas et al., 2016). But the other study showed that the number of seeds per fruit was low in S. melongena and their wild relatives (Devi et al., 2015).

\section{Pollen viability estimation}

Pollen viability of hybrids and their parents was found different. The INC, MEE and MEB were semi-fertile and showed pink color of pollen grains. The pollen grains of MEP gave dark red color and were highly fertile, i.e. $70.1 \%$ pollens were fertile, while $63.4 \%$ pollen were fertile in hybrid MEP x MEE. On the other hand, the least pollen viability (38.9\%) was observed in MEE x MEB. However, the maximum (65.04\%) semi-fertile pollens were observed in MEB parent and minimum semi-fertility 
was observed in $35.07 \%$. Pollen grain of MEExMEB gave pink color that indicated semi-fertile pollen while pollens of MEExINC and MEPxMEE were dark red colored indicating high fertility and so they can be used in further breeding program (Figure 2b). A previous study also reported wide range of variation for pollen viability in S. melongena, wild relatives and their hybrid progenies (Devi et al., 2015). Almost all the pollen was aborted and empty, only $1.2 \%$ appearing normal, and pollen fertility was also high with $77.7 \%$ stainable pollen which was also larger than that of the parents.

\section{Molecular analysis by SRAP markers}

SRAP analysis was also performed to confirm the hybridity of MEPxMEE, MEExINC and MEExMEB. For confirmation of hybridity, all plants were analyzed by SRAP markers, and the results showed that they had specific bands from the two parents (Figure 2c). Thus, all plants were true hybrids. Similarly, all hybrids were found to be true hybrids between 'Clementine' mandarin and K1 blood orange (Oruç \& Dalkiliç, 2017). Mishra et al. (2011) demonstrated the effectiveness of SRAP marker in genetic analysis and hybrid identification of intraspecific $C$. arabica coffee hybrids.

These results suggest that genotypic difference can result in variable results of heterosis observed for positive gain in fruit diameter and yield of $S$. melongena $\mathrm{x} S$. incanum. In this regard, this material will be of great interest for the genetic improvement of eggplant; it may have a tremendous potential to increase tolerance to abiotic stresses, such as to drought and heat, as well as increased the nutrient values and herbal values which will be helpful in improving the human health. Finally, we hope that this study opens the way for the incorporation of the $S$. incanum in new World gene pool for eggplant breeding, ultimately contributing to the development of a new generation of plants adapted to climate change and with improved nutritional, herbal, and diseases and pest resistance properties.

\section{REFERENCES}

ALEXANDER, M. 1969. Differential staining of aborted and non-aborted pollen. Stain Technology 44: 117-122.

BAHGAT, A; ABDEL AZIZ, H; RAAFAT, M; MAHDY, A; ELKHATIB, AS; ISMAIL, A; KHAYYAL, MT. 2008. Solanum indicum ssp. distichum extract is effective against 1-NAME-induced hypertension in rats. Fundamental \& Clinical Pharmacology 22: 693-699.

BEHERA, TK; SINGH, N. 2002. Interspecific crosses between eggplant (Solanum melongena $\mathrm{L}$.) with related Solanum species. Scientia Horticulturae 95: 165-172.

BUDAK, H; SHEARMAN, RC; PARMAKSIZ, I; DWEIKAT, I. 2004. Comparative analysis of seeded and vegetative biotype buffalo grasses based on phylogenetic relationship using ISSRs, SSRs, RAPDs, and SRAPs. Theoretical and Applied Genetics 109: 280-288.

COLLONNIER, C; MULYA, K; FOCK, I; MARISKA, I; SERVAES, A; VEDEL, F; YAKOVLEV, SS; SOUVANNAVONG, V; DUCEREUX, G; SIHACHAKR, D. 2001. Source of resistance against Ralstonia solanacearum in fertile somatic hybrids of eggplant (Solanum melongena L.) with Solanum aethiopicum L. Plant Science 160: 301-313.

DEMPEWOLF, H; EASTWOOD, RJ; GUARINO, L; KHOURY, CK; MÜLLER, JV; TOLL, J. 2014. Adapting agriculture to climate change: a global initiative to collect, conserve, and use crop wild relatives. Agroecology and Sustainable Food Systems 38: 369-377.

DEVI THE, CP; MUNSHI, AD; BEHERA, TK; CHOUDHARY, H; VINOD, B; GURUNG, P; SAHA. 2015. Cross compatibility in interspecific hybridization of eggplant, Solanum melongena, with its wild relatives. Scientia Horticulturae 193: 353-358.

GHANI, MA; ABBAS, MM; AMJAD, M; ZIAF, K; ALI, B; SHAHEEN, T; AWAN, FS; KHAN, AN. 2020. Production and characterisation of tomato derived from interspecific hybridisation between cultivated tomato and its wild relatives. The Journal of Horticultural Science and Biotechnology. 95: 506-520

GISBERT, C; PROHENS, J; RAIGÓN, MD; STOMMEL, JR; NUEZ, F. 2011. Eggplant relatives as sources of variation for developing new rootstocks: Effects of grafting on eggplant yield and fruit apparent quality and composition. Scientia Horticulturae 128: 14-22.

HAYDAR, A; MANDAL, MA; AHMED, MB; HANNAN, MM; KARIM, R. 2007. Studies on genetic variability and interrelationship among the different traits in tomato (Lycopersicon esculentum Mill.). Middle-East Journal of Scientific Research 2: 139-142.

KAUSHIK, P; PROHENS, J; VILANOVA, S; GRAMAZIO, P; PLAZAS, M. 2016. Phenotyping of eggplant wild relatives and interspecific hybrids with conventional and phenomics descriptors provides insight for their potential utilization in breeding. Frontiers in Plant Science 7: 677.

KUMAR, A; VINAY, S; BHARAT, TJ; PRASHANT K. 2020. Heterosis breeding in eggplant (Solanum melongena L.): Gains and Provocations. Plants 9: 403.

LI, G; QUIROS, CF. 2001. Sequence-related amplified polymorphism (SRAP) a new marker system based on a simple, PCR reaction: its application to mapping, and gene tagging in Brassica. Theoretical and Applied Genetics 103: 455-461.

LIU, J; ZHENG, Z; ZHOU, X; FENG, C; ZHUANG, Y. 2015. Improving the resistance of eggplant (Solanum melongena) to Verticillium wilt using wild species Solanum linnaeanum. Euphytica 201: 463-469.

MAGIOLI, C; MANSUR, E. 2005. Eggplant (Solanum melongena L.): tissue culture, genetic transformation and use as an alternative model plant. Acta Botanica Brasilica 19: 139148.

MANGINO, G; PLAZAS, M; VILANOVA, S; PROHENS, J; GRAMAZIO, P. 2020. Performance of a set of eggplant (Solanum melongena) lines with introgressions from its wild relative $S$. incanum under open field and screenhouse conditions and detection of QTLs. Agronomy 10: 1-16. doi:10.3390/ agronomy 10040467.

MISHRA, MK; BHAT, AM; SURESH, N; SATHEESH, KS; PADMAJYOTHI, D; PRAKASH, NS. 2011. Molecular genetic analysis of arabica coffee hybrids using SRAP marker approach. Journal of Plantation Crops 39: 41-47.

MWAURA, L; ANJARWALLA, P; FORI, DA; STEVENSON, PC; SMITH, P; JAMNADASS, R. 2011. Solanum incanum L. Pesticidal Plant Leaflet.

NASRALLAH, ME; HOPP, RJ. 1963. Interspecific crosses between Solanum melongena L. (eggplant) and related Solanum species. Proceedings of the American Society for Horticultural Science 83: 571-574.

ORUÇ, G; DALKILIÇ, Z. 2017. Pollen characteristics of blood oranges and determination of hybrids with SRAP markers. Romanian Biotechnological Letters 22: 12377-12388.

PLAZAS, M; VILANOVA, S; GRAMAZIO, P; RODRIGUEZ-BURRUEZO, A; RAJAKAPASHA, R; RAMYA, F; NIRAN L, FONSEKA; H, KOUASSI, B; KOUASSI, A; KOUASSI, A; PROHENS, J. 2016. Interspecific hybridization between eggplant and wild relatives from different gene pools. Journal of the American Society of Horticultural Science 141: 34-44.

PROHENS, J; WHITAKER, BD; PLAZAS, M; VILANOVA, S; HURTADO, M; BLASCO, M; GRAMAZIO, P; STOMMEL, JR. 2013. Genetic diversity in morphological characters and phenolic acids content resulting from an interspecific cross between eggplant, Solanum melongena, and its wild ancestor (S. incanum). Annals of Applied Biology 
162: 242-257.

SEKARA, A; CEBULA, S; KUMAR, E. 2007. Cultivated eggplant: Origin, breeding objectives and genetic resources a review. Folia Horticulturae 19: 97-114.

SHAKOOR, A; SABRI, MA; AFZAL, M; BASHIR, MH. 2010. Role of plant morphological characters towards resistance of some cultivars of tomato against phytophagous mites (Acari) under greenhouse conditions.
Pakistan Journal of Life and Social Sciences 8: 131-136.

TAHER, D; SOLBERG, SØ; PROHENS, J; CHOU, Y; RAKHA, M; WU, T. 2017. World vegetable center eggplant collection: Origin, composition, seed dissemination and utilization in breeding. Frontiers in Plant Science 8: 1484. doi: 10.3389/fpls.2017.01484.

TYACK, N; DEMPEWOLF, H. 2015. The economics of crop wild relatives under climate change. Crop Wild Relatives and Climate Change. Hoboken, NJ: John Wiley \& Sons, Inc. USA, p.281-291.

WAWERU, CM; MUTHAMIA, JM; OTAYE, DO. 2017. Potential of sodom apple (Solanum incanum L.) Fruit extracts in the management of chilli root knot disease in Nakuru County, Kenya. Advances in Agriculture. Article ID 3849829, 1-5. Available at https://doi. org/10.1155/2017/3849829. 